\title{
ANALISIS KETERAMPILAN MEMBACA PERMULAAN SISWA SEKOLAH DASAR: STUDI KASUS PADA SISWA KELAS 2 SEKOLAH DASAR
}

\author{
Cerianing Putri Pratiwi \\ Fakultas Keguruan dan Ilmu Pendidikan, Universitas PGRI Madiun \\ email: cerianing@unipma.ac.id
}

\begin{abstract}
The purpose of this study is (1) to find out the faktors that lead to low competency in reading students and (2) how students learn to read activities at school and at home. The type of this study is qualitative which uses a case study method. The subjects of this study were Second grade students at SDN Tanjung 3 who had difficulty reading. Data collection techniques used in this study are observation, interviews, and documentation. The data validation used in this study is source triangulation. Data analysis techniques use interactive model data analysis, namely data reduction, data presentation, and conclusion or verification. The results of this study are, (1) the faktors that cause low reading competence in $R A$ are derived from psychological and environmental faktors. Psychological faktors, from within students themselves in the form of lack of interest in learning to read students and socio and emotional maturity and adjustment. Environmental faktors come from lack of attention and guidance from both parents. (2) Learning activities for reading students at school and at home are lacking, because these students play more.
\end{abstract}

Keyword: Skill, Reading the Beginning, Case Study

\begin{abstract}
Abstrak: Tujuan dari penelitian ini adalah (1) mengetahui faktor-faktor yang menyebabkan rendahnya kompetensi membaca siswa dan (2) bagaimana aktivitas belajar membaca siswa di sekolah dan di rumah. Jenis penelitian ini adalah kualitatif dengan menggunakan metode studi kasus. Subjek dari penelitian ini siswa kelas 2 SDN Tanjung 3 yang mengalami kesulitan membaca. Teknik pengumpulan data yang digunakan pada penelitian ini yaitu observasi, wawancara, dan dokumentasi. Validasi data yang digunakan pada penelitian ini yaitu triangulasi sumber. Teknik analisis data menggunakan analisis data model interaktif yaitu reduksi data, penyajian data, dan penarikan kesimpulan atau verifikasi. Hasil penelitian ini yaitu (1) faktor yang menyebabkan rendahnya kompetensi membaca pada RA adalah berasal dari faktor psikologis dan lingkungan. Faktor psikologis, dari dalam diri siswa sendiri berupa kurang berminatnya siswa dalam belajar membaca dan kematangan sosio dan emosi serta penyesuaian diri. Faktor lingkungan berasal dari kurang perhatian dan bimbingan dari kedua orangtuanya. (2) Aktivitas belajar membaca siswa di sekolah dan di rumah kurang, karena siswa tersebut lebih banyak bermain.
\end{abstract}

Kata kunci: Keterampilan, Membaca Permulaan, Studi Kasus

\section{PENDAHULUAN}

Bahasa dan komunikasi memiliki hubungan yang sangat terkait. Keduanya merupakan aspek perkembangan yang memiliki peran penting dalam kehidupan manusia. Seseorang yang tidak memiliki kemampuan bahasa dan komunikasi, akan sulit untuk berinteraksi dengan sesamanya. Bahasa merupakan suatu bentuk dari kode sosial yang dapat digunakan dalam berkomunikasi. Selanjutnya, suatu proses berinteraksi dengan orang lain disebut dengan komunikasi.

Manusia tidak akan lepas dari Bahasa, karena bahasa selalu digunakan setiap manusia untuk kehidupannya sehingga bahasa sering dikatakan milik manusia. Dalam segala aspek kehidupan manusia menggunakan bahasa. Bahasa merupakan alat untuk menyampaikan isi 
pikiran, bahasa juga untuk berkomunikasi, bahasa merupakan alat untuk berinteraksi. Dalam bahasa terdapat empat keterampilan bahasa yang harus dikuasai atau diajarkan kepada peserta didik pada saat duduk di bangku sekolah. Keterampilan dalam bahasa ada empat yaitu menyimak berbicara, membaca, dan menulis. Sependapat dengan Tarigan (2008) bahwa kurikulum sekolah ada 4 yaitu menyimak, berbicara, membaca, dan menulis merupakan keterampilan bahasa yang terdapat pada kurikulum sekolah. Keterampilan menyimak dan berbicara merupakan keterampilan dalam komunikasi lisan, sedangkan keterampilan membaca dan menulis termasuk kemampuan tulis.

Keterampilan bahasa dapat diperoleh melalui suatu hubungan dengan manusia. Keterampilan pertama yang dimiliki sesorang yaitu keterampilan menyimak atau mendengarkan bahasa, keterampilan kedua yaitu keterampilan berbicara, sesudah itu keterampilan yang dimiliki seorang yaitu keterampilan membaca dan yang terakhir yaitu keterampilan menulis. Keterampilan menyimak sudah mulai dimengerti seseorang sejak dalam kandungan. Sebelum memasuki usia sekolah sudah mempejalari keterampilan berbicara, sedangkan kedua membaca dan menulis dipelajari pada saat usia sekolah.

Manusia tidak bisa lepas dari bahasa, oleh sebab itu belajar bahasa suatu hal yang tidak dapat pisah dari kehidupan manusia terutama di Sekolah Dasar (Rahman, 2014). Hasanudin dan Puspita (2017) menambahkan bahwa membaca merupakan salah satu aspek ruang lingkup dalam pembelajaran bahasa Indonesia baik di sekolah dasar maupun sekolah menengah.

Membaca merupakan salah satu keterampilan yang dipelajari pada usia sekolah. Membaca merupakan satu dari empat keterampilan bahasa pokok, serta merupakan komunikasi tulis. Abidin (2012) menyatakan, membaca merupakan kegiatan yang dilakukan untuk mendapatkan informasi yang ada pada sebuah bahan bacaan. Dengan membaca akan mendapatkan pemahaman atas isi bacaan. Saddhono dan Slamet (2014) menjelaskan membaca merupakan suatu kegiatan untuk memahami sebuah isi baik yang tersurat maupun yang tersirat dalam suatu bacaan. Membaca merupakan suatu aktivitas yang kompleks karena mengikutsertakan kemampuan mengingat symbol grafis yang terdapat pada kata dan kalimat yang didalamnya terselip sebuah makna.

Oleh karena itu, keterampilan membaca perlu dilandasi dengan kemampuan kognitif. Hal tersebut menunjukkan bahwa kesulitan membaca dapat disebabkan karena ketidakmapuan dalam operasi kognitif. Di samping itu, membaca juga membutuhkan pemusatan perhatian seseorang ketika membaca. Kemampuan membaca juga berkaitan dengan kemampuan dalam proses sensomotor.

Berdasarkan hasil observasi pada siswa kelas 2 SDN Tanjung 3, dapat diketahui bahwa ada siswa yang masih mengalami kesulitan membaca permulaan. Siswa tersebut masih belum bisa merangkai huruf menjadi sebuah kata dan kata menjadi kalimat. Kesulitan membaca yang dialami siswa tersebut menjadikan siswa tersebut kurang berminat pada pembelajaran. Hasanudin (2016) menjelaskan bahwa mengajar membaca permulaan memang membutuhkan kesabaran yang luar biasa, kesabaran itu dibutuhkan karena objek yang diajar adalah masih anak-anak. Anak-anak memang memiliki kecenderungan untuk bermain daripada belajar. Widyaningrum dan Hasanudin (2019) menambahkan bahwa pihak guru pun juga mempunyai andil besar untuk menumbuhkan minat baca anak didiknya

Kemampuan membaca menulis permulaan bertujuan untuk membantu anak mengomunikasikan ide serta perasaan kepada orang lain (Christianti, 2013). Membaca memiliki banyak manfaat. Dengan membaca seseorang akan mendapatkan pengetahuan yang luas, dengan lancar membaca akan berpengaruh terhadap pembelajaran yang lainnya. Apabila anak kesulitan membaca akan menghambat penguasaan ilmunya. Hal itu karena keterampilan tersebut merupakan dasar pelajaran bagi kelas selanjutnya (Mustikowati, 2016). 
Selain itu, membaca juga memiliki banyak manfaat lainnya seperti pendapat Saddhono dan Slamet (2014) menyatakan bahwa manfaat membaca yaitu mendapatkan pengalaman yang berguna bagi kehidupann; memperoleh pengetahuan dan informasi; mengetahui banyak peristiwa tentang peradaban dan kebudayaan suatu bangsa; mengetahui perkembangan iptek; memperluas cara pandang dan pola pikir; mengantarkan pembaca menjadi seseorang yang cerdik serta pandai; menambah pembendaharaan kosakata, ungkapan, istilah, sehingga dapat digunakan untuk menunjang keterampilan menyimak, berbicara, membaca, dan menulis; menjadikan potensialitas seseorang lebih tinggi, dan eksistensi menjadi lebih mantap.

Banyak sebab yang menjadikan siswa kurang lancar membaca, sebab tersebut dapat berasal yaitu faktor intern (dalam) dan faktor ekstern (luar). Faktor intern yang dimaksud yaitu semua faktor yang berasal seseorang (siswa) itu sendiri, sedangkan yang dimaksud faktor ekstern yaitu faktor yang asalnya dari luar atau selain dari diri siswa. Faktor ekstern ini dapat berupa situasi dan kondisi lingkungan yang tidak mendukung terutama dalam aktivitas belajar siswa. Hal itu hampir sama dengan pendapat Slamet (2008) yang menyebabkan siswa mengalami kesulitan belajar ada dua faktor yaitu internal dan eksternal. Faktor internal dapat berupa kemungkinan adanya disfungsi neurologis. Sedangkan faktor eksternal merupakan penyebab utama problem anak. Faktor eksternal yang dimaksud adalah strategi belajar yang salah, pengelolaan kegiatan belajar yang belum meningkatkan motivasi belajar anak.

Menurut Lamb dan Arnold (dalam Rahim 2011) faktor yang dapat berpengaruh pada keterampilan membaca permulaan yaitu faktor fisiologis, faktor intelektual, faktor lingkungan, dan faktor psikologis. Yang termasuk dalam faktor fisiologis yaitu kesehatan yang berhubungan dengan fisik, pertimbangan neurologis, dan jenis kelamin. Gangguan intelegensi dapat diartikan sebagai suatu kegiatan berpikir yang terdiri dari pemahaman esensial tentang situasi yang diberikan dan dapat merespon secara tepat. Faktor lingkungan yaitu latar belakang dan pengalaman anak serta faktor sosial ekonomi. Faktor psikologis meliputi minat, motivasi, kematangan sosio dan emosi anak.

Kajian yang relevan dengan penelitian ini yaitu penelitain dengan judul Analisis Kesulitan Belajar dalam Pembelajaran Membaca Cepat Siswa Kelas v SD Gugus 6 Kecamatan Abang oleh Januarti, Dibia, Widiana (2016). Kesamaan penelitian ini dengan penelitian tersebut yaitu keduanya membahas tentang kemampuan membaca pada siswa SD. Akan tetapi, kedua penelitian ini memiliki perbedaan, yaitu pada penelitain tersebut menganalisis kesulitan membaca cepat, sedangkan penelitian ini mengkaji membaca permulaan. Membaca permulaan ini termasuk membaca paling awal pada tingkat sekolah dasar sehingga memerlukan analisis yang lebih mendalam tentang kemampuan siswanya, setelah itu baru meningkat pada jenis membaca lainnya, misalkan membaca cepat.

Kajian relevan yang kedua yaitu penelitian dengan judul Analsiis Kesulitan Siswa Dalam Membaca Permulaan di Kelas Satu Sekolah dasar oleh Pratiwi dan Ariawan (2017). Persamaan kedua penelitian ini yaitu keduanya membahas tentang kemampuan membaca permulaan. Akan tetapi, kedua penelitian ini memiliki perbedaan yaitu pada penelitian tersebut lebih fokus pada kesulitan membaca permulaan pada semua siswa kelas 1 sedangkan pada penelitian ini lebih fokus pada siswa yang mempunyai masalah pada kemampuan membaca yang dilihat dari kegiatan siswa dalam membaca permulaan serta faktor-faktor yang mempengaruhinya.

Berdasarkan uraian di atas, maka penelitian ini memiliki tujuan yaitu (1) mengetahui faktor penyebab rendahnya kompetensi membaca siswa dan (2) mengetahui kegiatan belajar membaca siswa di sekolah dan di rumah.

\section{METODE PENELITIAN}

Penelitian ini termasuk dalam penelitian deskriptif kualitatif dengan 
metode studi kasus (case study), yaitu penelitian yang tentang individu, kelompok, satu organisasi dalam waktu tertentu (Arifin, 2011). Subjek pada penelitian ini yaitu siswa kelas 2 yang mengalami kesulitan membaca.

Data primer dalam penelitian ini adalah subjek khusus yang mengalami rendahnya kompetensi membaca, beberapa teman satu kelas, guru, kepala sekolah, orang tua, dan juga wali kelas. Data sekunder dalam penelitian ini yaitu hasil belajar subjek khusus di sekolah yang berupa daftar nilai tugas, ujian dan juga nilai dalam raport. Penelitian ini teknik pengumpulan datanya yaitu (a) observasi, (b) wawancara, (c) dokumentasi. Menggunakan validasi data yaitu teknik triangulasi sumber. Dengan menggunakan triangulasi sumber ini, peneliti dalam pengumpulan data wajib menerapkan berbagai sumber data yang berbeda. Teknik analisis data data model interaktif yaitu teknik analisis yang digunakan pada penelitian ini. Menurut Miles dan Huberman (1992) ada tiga hal utama dalam analisis data model interaktif yaitu reduksi data, penyajian data, dan penarikan kesimpulan atau verifikasi.

Prosedur penelitian ini yaitu diawali dengan tahap pendahuluan, di mana melakukan survei pada sekolah untuk mengetahui keterampilan membaca siswa. Pada tahap pendahuluan juga dilakukan penelusuran literatur buku dan referensi pendukung penelitian. Tahap kedua yaitu, tahap pelaksanaan yaitu pengumpulan data sebanyak mungkin. Tahap ketiga yaitu tahap penyelesaian. Pada tahap ini peneliti menganalisis data berdasarkan hasil temuan peneliti dari hasil observasi, wawancara, dan dokumentasi.

\section{HASIL DAN PEMBAHASAN}

Subjek yang diteliti pada penelitian ini yaitu bernama RA, dia siswa kelas 2 di SDN Tanjung 3. RA adalah seorang siswa berjenis kelamin laki-laki. Saat ini usianya 8 tahun. Ayah RA bekerja sebagai buruh tani, sedangkan ibunya juga sebagai buruh tani. RA tinggal bersama orangtuanya dan satu orang adiknya. Rumah yang ditempati RA cukup sederhana. Dilihat dari ekonomi keluarga, RA termasuk dalam ekonomi menengah ke bawah. Sumber pendapatan keluarga ini bergantung pada penghasilan ayah dan ibunya yang belum tentu setiap hari ada pekerjaan. RA pada saat ini masih belum lancar membaca. Untuk mengetahui faktor yang sedang dihadapi siswa tersebut dilakukan pengamatan dan pendekatan.

\section{Faktor Penyebab Rendahnya Kompetensi Membaca RA \\ Berdasarkan observasi, dapat} diketahui, faktor penyebab rendahnya kompetensi membaca RA yaitu faktor lingkungan dan psikologis. Faktor psikologis yang menyebabkan rendahnya kompetensi membaca RA yaitu lemahnya minat membaca siswa. RA kelihatan tidak berminat dalam membaca. Hal itu tampak pada saat guru menugasi membaca, tetapi RA diam saja tidak mau membaca. Padahal seseorang yang mempunyai minat membaca yang tinggi akan mewujudkaannya dalam kesediaan untuk membaca atas kesadarannya sendiri. Selain minat, faktor lain yang mempengaruhi rendahnya kompetensi membaca RA yaitu kematangan sosio dan emosi serta penyesuaian diri.

Menurut guru kelas 2 SDN Tanjung 3, faktor yang menyebabkan RA belum lancar membaca yaitu faktor dari diri siswa sendiri dan orang tua. Faktor dari diri sendiri yaitu siswa yang kurang mempunyai minat dalam membaca. Selain itu, menurut penuturan guru, siswa tersebut sulit untuk diarahkan, pada saat pembelajaran, siswa tersebut sering berbicara sendiri atau mengganggu teman yang lainnya. Apabila diberi tambahan untuk belajar membaca, siswa tersebut tidak mau. Faktor dari orang tua yaitu kurang adanya dorongan belajar dari orang tua, kurang perhatian dari orang tua. Berikut kutipan wawancara dengan guru.

"RA itu masih belum lancar membaca. Faktornya bisa dari internal dan eksternal. Internal berasal dari RA sendiri, kalau diarahkan suka diam saja. Kalau di dalam kelas, suka mengganggu temannya, kalau disuruh membaca dia diam, kadang kelihatan takut." 
Berdasarkan hasil penelitian yang telah dilakukan, diketahui bahwa RA siswa kelas 2 SDN Tanjung 3 ini belum lancar membaca. RA sudah bisa mengenal huruf tetapi untuk merangkai dan membacanya belum lancar. Faktor-faktor penyebab rendahnya kompetensi membaca RA yaitu faktor psikologis dan faktor lingkungan. Faktor psikologis yang menyebabkan RA belum lancar membaca yaitu minat. Padahal minat sangat mempengaruhi kegiatan membaca. Hal itu sejalan dengan pendapat Widiyati (2014) kegiatan membaca melibatkan aspek berpikir, emosi, dan aspek minat. Yetti (2009) menyatakan Aktivitas membaca akan dilakukan atau tidak oleh anak, sangat ditentukan oleh minat anak terhadap suatu aktivitas tersebut. RA kurang berminat pada pembelajaran membaca, apabila disuruh membaca ia tidak mau. Selain minat, faktor dari dalam diri RA juga yang menyebabkan ia belum lancar untuk membaca yaitu kematangan sosio dan emosi serta penyesuaian diri. RA pada saat ini berusia 8 tahun yang memiliki kestabilan emosi yang kurang. RA cenderung mudah marah dan menangis jika teman-temannya menyuruh untuk membaca.

RA jarang meminta bantuan kepada temannya untuk mengajarkan membaca. RA juga enggan apabila diberi tambahan guru untuk belajar membaca, ia lebih senang bermain bersama teman-temannya daripada belajar membaca. Pada proses pembelajaran berlangsung RA sering mengganggu temannya dengan mengajak berbiacara atau mengambil buku temannya. Hal itu menyebabkan temannya terganggu. Selain itu, pada saat pembelajaran, RA kurang berkonsentrasi, kurang memperhatikan pembelajaran, sehingga RA tidak paham dengan pelajaran yang disampaikan gurunya. RA lebih sering tidak mau membaca apabila ditugasi guru untuk membaca. Ia diam saja dan kadang tampak takut apabila ditugasi untuk membaca. Oleh karena itu, hingga saat ini RA belum lancar membaca.

Selain faktor psikologis, faktor lainnya yang menjadi pengaruh rendahnya kemampuan membaca RA yaitu faktor lingkungan. Faktor lingkungan ini berasal dari lingkungan keluarganya. Lingkungan dapat mempengaruhi atau dapat membentuk pribadi, sikap, nilai, dan kemampuan bahasa anak. Keadaan di rumah mempengaruhi pribadi dan penyesuaian diri anak dalam masyarakat. Keadaan tersebut dapat membantu anak, dan juga dapat menghalangi anak belajar membaca. Orang tua RA yang kurang perhatian, kurang ikut berpartisipasi pada proses belajar sang anak sehingga menyebabkan RA jarang belajar di rumah ia lebih banyak bermain. Hal itu juga menyebabkan RA belum dapat membaca lancar.

Sementara kendala yang dihadapi guru wali kelas dalam menangani siswa belum lancar membaca seperti RA ini ialah dari segi kemauan anak sendiri, RA sering bermalas-malasan, kurangnya usaha dari dalam dirinya untuk bisa membaca. Jika guru memberikan motivasi kepada siswa, namun tidak ditambahi dengan motivasi dari dalam diri siswa, maka hal ini akan menjadi sangat susah untuk memberikan perkembangan kepada siswa itu.

Selain itu, orang tua RA yang kurang mendukung dalam kegiatan pembelajaran di rumah juga menjadi kendala guru. Apabila guru di sekolah sudah telaten, ulet memberikan pengajaran di sekolah, namun di rumah jarang diperhatikan, maka hasilnya RA tidak memperhatikan dirinya sendiri masih bermalas-malasan, jarang mengerjakan PR. Perkembangan membaca anak membutuhkan motivasi dari orangtuanya dan minat dari diri sendiri. Hal itu sejalan dengan pendapat Jauhari (2013) Anak-anak sangat membutuhkan lingkungan yang memperkaya khasanah bahasanya dan yang memotivasi untuk belajar membaca. Selain itu dari penelitian yang terdahulu oleh Januarti, Dibia, Widiana (2016) juga mengatakan bahwa faktor yang mempengaruhi dalam membaca cepat yakni, konsetrasi dan gerakan mata pada saat membaca cepat. Hal tersebut menunjukkan bahwa konsentrasi siswa sangat berpengaruh terhadap kemampuan membaca. 


\section{Aktivitas Belajar Membaca RA di Sekolah dan di Rumah}

Berdasarkan hasil observasi pada pembelajaran membaca siswa kelas 2 SDN Tanjung 3, dapat diketahui bahwa RA kurang aktif dalam mengikuti pembelajaran. Jika guru menyuruh RA untuk membaca, siswa tersebut akan diam dan kelihatan akan menangis. Pada saat pembelajaran, RA juga terlihat mengganggu atau mengajak ngobrol teman satu bangkunya atau teman disekitar bangkunya. Teman-temannya jadi tidak konsentrasi dalam pembelajaran.

Berdasarkan wawancara dengan teman sekelas RA, juga dapat diketahui bahwa RA belum lancar membaca. Pada saat pembelajaran membaca RA sering diam saja dan kadang menganggu temannya saat membaca. Berikut kutipan wawancara dengan teman sekelas RA.

"RA itu kalau di kelas suka
mengganggu teman, anaknya suka
ramai sendiri. Kalau sama bu guru
disuruh membaca, RA tidak mau."

Aktivitas belajar membaca RA hanya terjadi di sekolah saja, pada saat di rumah RA tidak belajar. Ia lebih senang bermain bersama teman-temannya. Selain itu, orang tuanya juga jarang menyuruh RA untuk belajar. Ketika belajar RA jarang didampingi oleh orang tuanya. Berikut hasil wawancara dengan RA.

$\begin{array}{lll}P N & \text { :Apakah di rumah selalu belajar? } \\ R A & : \text { tidak } \\ P N & \text { :Kalau tidak belajar, kegiatan di } \\ & \text { rumahnya apa saja? } \\ R A & \text { : bermain } \\ P N & \text { :Apakah orang tua selalu } \\ & \text { menyuruh untukbelajar? } \\ R A & : \text { Kadang-kadang } \\ P N & \text { :Apakah orang tua selalu } \\ & \text { mendampingi RA pada saat } \\ & \text { belajar? } \\ R A & : \text { Kadang ditemani ibu }\end{array}$

Aktivitas belajar membaca RA di sekolah yaitu RA masih tampak tidak berminat pada pembelajaran membaca. Selain itu, RA di kelas suka ramai dan mengganggu temannya saat pembelajaran berlangsung. Untuk aktivitas membaca RA di sekolah masih kurang. Hal itu disebabkan RA apabila ditugasi untuk membaca tidak mau. Guru sering menawari RA untuk tambahan belajar membaca, tetapi RA selalu menolak. Aktivitas membaca RA di rumah juga masih kurang. Pada saat di rumah, RA juga sering tidak belajar membaca karena kurang adanya bimbingan dari orang tua. Hal itu dikarenakan, kurangnya perhatian dari orang tua, sehingga menyebabkan RA tidak belajar. Orang tua jarang menyuruh RA untuk belajar. RA lebih banyak bermain dan jarang mengerjakan PR ataupun tugas lainnya. Hal tersebut menyebabkan RA masih belum dapat membaca lancar. Widyaningrum dan Hasanudin (2019) menjelaskan bahwa kurangya perhatian orang tua berpengaruh dalam diri siswa, contohnya saat siswa tidak mau belajar dan lebih suka menonton tv orang tua hanya diam saja tanpa menegur.

\section{SIMPULAN}

Simpulan penelitian ini adalah 1) Faktor Penyebab Rendahnya Kompetensi Membaca RA yaitu faktor psikologis dan faktor lingkungan. Faktor psikologis dari dalam diri siswa sendiri yang kurang berminat pada membaca dan kematangan sosio dan emosi serta penyesuaian diri. Faktor lingkungan berasal dari kurang perhatian dan bimbingan dari kedua orangtuanya. 2) Aktivitas Belajar RA di Sekolah suka ramai, mengganggu temannya saat pelajaran, dan jarang berkonsentrasi saat guru menjelaskan. Sementara itu, kegiatan belajarnya di rumah juga tidak maksimal karena RA sering bermain sehingga jarang mengerjakan PR ataupun tugas lainnya.

Berdasarkan simpulan di atas, maka diharapkan guru terus memantau kemampuan membaca anak, selalu memberikan dukungan pada siswa agar minat belajar siswa meningkat. Selain itu, orang tua juga harus turut aktif dalam meningkatkan kemampuan membaca siswa. Memberikan perhatian dan dukungan pada anak, akan menambah semangat anak dalam belajar. 


\section{DAFTAR RUJUKAN}

Abidin, Y. (2012). Pembelajaran bahasa berbasis pendidikan karakter. Bandung: PT Refika Aditama.

Arifin, Z. (2011). Penelitian pendidikan. Bandung: PT Remaja Rosdakarya Offset.

Christianti, M. (2013). Membaca dan menulis permulaan untuk anak usia dini. Jurnal Pendidikan Anak, 2(2), 312-317.

Hasanudin, C. (2016). Pembelajaran membaca permulaan dengan menggunakan media aplikasi bamboomedia bmgames apps pintar membaca sebagai upaya pembentukan karakter siswa sd menghadapi MEA. PEDAGOGIA: Jurnal Pendidikan, 5(1), 1-12. Doi http://doi.org/10.21070/pedagogia.v5 i1.84.

Hasanudin, C. dan Puspita, E. L. (2017). Peningkatan motivasi dan keterampilan membaca permulaan siswa kelas i melalui media aplikasi bamboomedia bmgames apps. PEDAGOGIA: Jurnal Pendidikan, 6(1), 1-13. Doi http://doi.org/10.21070/pedagogia.v6 i1.618.

Januarti, D. W. (2016). Analisis kesulitan belajar dalam pembelajaran membca cepat siswa kelas $\mathrm{v}$ SD gugus 6 Kecamatan Abang. e-Journal PGSD Universitas Pendidikan Ganesha, 1(4), 1-10.

Jauhari, S., Marhaeni, A. A. I. N., \& Sutama, M. (2013). Pengaruh implementasi strategi dia tampan berbantuan media audio visual terhadap hasil belajar membaca permulaan. Jurnal Pendidikan Dasar, 3(1), 1-9.

Miles, M. dan Huberman, M. (1992). Analisis data kualitatif. Jakarta: Universitas Indonesia.
Musaba, Z. (2012). Bahasa Indonesia untuk mahasiswa. Yogyakarta: CV. Aswaja Pressindo.

Mustikowati, D., \& Wijayanti, E. (2016). Meningkatkan semangat membaca dan menulis siswa sekolah dasar dengan permainan kata bersambut. Briliant: Jurnal Riset dan Konseptual, 1(1), 39-42.

Pratiwi dan Ariawan. (2017). Analsiis kesulitan siswa dalam membaca permulaan di kelas satu sekolah dasar. Sekolah Dasar, 26(1), 69-76.

Rahim, F. (2011). Pengajaran membaca di sekolah dasar. Jakarta: PT Bumi Aksara.

Rahman, B., \& Haryanto, H. (2014). Peningkatan keterampilan membaca permulaan melalui media flashcard pada siswa kelas I SDN Bajayau Tengah 2. Jurnal Prima Edukasia, 2(2), 127-137.

Saddhono, K dan Slamet. (2014). Pembelajaran keterampilan berbahasa Indonesia. Yogyakarta: Graha Ilmu.

Slamet. (2008). Dasar-dasar pembelajaran bahasa dan sastra Indonesia di sekolah dasar. Surakarta: UNS Press.

Widyaningrum, H. K. dan Hasanudin, C. (2019). Kajian kesulitan belajar Membaca Menulis Permulaan (MMP) pada siswa kelas II [Study of Difficulty Learning to Read Beginning Writing (MMP) in Class II Students], PEDAGOGIA: Jurnal Pendidikan, 8(2), 189-200. Doi https://doi.org/10.21070/pedagogia.v $\underline{8 \mathrm{i} 2.2219}$.

Widyaningrum, H. K. dan Hasanudin, C. (2019). koleksi bahan pustaka dan minat baca siswa terhadap keterampilan menulis cerita narasi, Konferensi Nasional Bahasa dan Sastra V tentang Bahasa, Sastra, 
8 JURNAL PENDIDIKAN EDUTAMA, Vol.7, No.1 Januari 2020

Literasi, dan Pengajarannya serta Upaya Mendinamisasi Perbukuan Nasional. Prosiding Konferensi Prodi S3 PBI, FKIP, Universitas Sebelas Maret Surakarta, kolaborasi dengan ADOBSI dan PPJB-SIP, Surakarta, Indonesia. Retrieved from https://www.jurnal.fkip.uns.ac.id/ind ex.php/knbs/article/view/12880. 